\title{
ANTHELMINTIC ACTIVITY OF LAPACHOL, $\beta$-LAPACHONE AND ITS DERIVATIVES AGAINST Toxocara canis LARVAE
}

\author{
Taís MATA-SANTOS(1), Nitza França PINTO(1), Hilton Antônio MATA-SANTOS(2), Kelly Gallan DE MOURA(3), Paula Fernandes CARNEIRO(3), \\ Tatiane dos Santos CARVAlHO(3), Karina Pena DEL RIO(3), Maria do Carmo Freire Ribeiro PINTO(3), Lourdes Rodrigues MARTINS(1), \\ Juliana Montelli FENALTI(1), Pedro Eduardo Almeida DA SILVA(4) \& Carlos James SCAINI(1)
}

\begin{abstract}
SUMMARY
Anthelmintics used for intestinal helminthiasis treatment are generally effective; however, their effectiveness in tissue parasitosis (i.e. visceral toxocariasis) is moderate. The aim of this study was to evaluate the in vitro activity of lapachol, $\beta$-lapachone and phenazines in relation to the viability of Toxocara canis larvae. A concentration of $2 \mathrm{mg} / \mathrm{mL}$ (in duplicate) of the compounds was tested using microculture plates containing Toxocara canis larvae in an RPMI-1640 environment, incubated at $37{ }^{\circ} \mathrm{C}$ in $5 \% \mathrm{CO}_{2}$ tension for 48 hours. In the $2 \mathrm{mg} / \mathrm{mL}$ concentration, four phenazines, lapachol and three of its derivatives presented a larvicide/larvistatic activity of $100 \%$. Then, the minimum larvicide/larvistatic concentration (MLC) test was conducted. The compounds that presented the best results were nor-lapachol (MLC, $1 \mathrm{mg} / \mathrm{mL}$ ), lapachol (MLC $0.5 \mathrm{mg} / \mathrm{mL}$ ), $\beta$-lapachone, and $\beta$-C-allyl-lawsone (MLC, $0.25 \mathrm{mg} / \mathrm{mL}$ ). The larvae exposed to the compounds, at best MLC with $100 \%$ in vitro activity larvicide, were inoculated into healthy BALB/c mice and were not capable of causing infection, confirming the larvicide potential in vitro of these compounds.
\end{abstract}

KEYWORDS: Toxocara canis; Quinones; Chemotherapy; Anthelmintics.

\section{INTRODUCTION}

Human visceral toxocariasis is a neglected zoonotic infection caused by the larvae of Toxocara canis and, less frequently, Toxocara $c_{a t i}{ }^{31}$. According to recent reports, their prevalence seems to be underestimated mainly because of the difficulties of diagnosis and non-specific symptomatology ${ }^{36}$. The symptoms of this parasitic disease are characterized by cutaneous reactions, extensive eosinophilia, hepatomegaly, myocarditis, pulmonary infiltrates, and nodules accompanied by cough and fever ${ }^{13,18}$. The severity of symptoms depends on the location of the larvae and the number of larvae housed in tissues, which induces mechanical damage and, in turn, results in an immunemediated inflammatory response ${ }^{26}$. Therefore, death is frequently associated with inflammatory granulomatous reactions around the larvae ${ }^{15}$, which may persist for a long time and, with it, reactivated larval migration into the eye or the brain may occur at any time ${ }^{40}$. The long-term survival of $T$. canis larvae has been attributed to molecular strategies evolved by the parasite ${ }^{26}$.

Generally, the drugs used to treat this disease have limited effectiveness, such as diethylcarbamazine and thiabendazole faced with poor tolerability and the need for prolonged use $\mathrm{e}^{30}$. The low water solubility of benzimidazole compounds appears to collaborate with the low bioavailability of compounds in this group, such as albendazole ${ }^{38}$, the drug of choice in the treatment of visceral toxocariasis ${ }^{9}$. Nevertheless, albendazole is the drug that crosses the blood brain barrier ${ }^{34}$ and shows results superior to thiabendazole ${ }^{37}$ and diethylcarbamazine, because it does not reduce the levels of specific IgE and produces side effects in treated patients ${ }^{25}$. Therefore, an effective drug for treating human infections caused by $T$. canis is still needed ${ }^{28}$.

Among the possibilities of assisting in the treatment of visceral toxocariasis, natural and synthetic products ${ }^{33}$ stand out. Plant extracts are important sources of biologically active natural products and may be a model for the development of new drugs ${ }^{12,32}$.

Lapachol, an important representative of the quinone group, is isolated from plants of the Bignoniaceae family ${ }^{19}$. It performs biological activities against several pathogens, especially anti-parasitic activities against Trypanosoma cruzi, Schistosoma mansoni, Leishmania amazonensis and L. braziliensis S $^{7,23}$.

$\beta$-lapachone is an ortho-naphthoquinone, a natural derivative of lapachol, present in small quantities in the woods of Tabebuia spp (Bignoniaceae). $\beta$-lapachone is easily synthesized by sulfuric acid treatment of lapachol ${ }^{16}$ and has a wide range of biological activities, including trypanocidal, antibacterial, anti-inflammatory, and anticancer activity $^{2,3,4,7,29}$. 


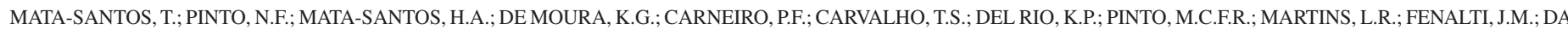
SILVA, P.E.A. \& SCAINI, C.J. - Anthelmintic activity of lapachol, $\beta$-lapachone and its derivatives against Toxocara canis larvae. Rev. Inst. Med. Trop. Sao Paulo, 57(3): 197-204, 2015.

Several heterocyclic compounds were synthesized from $\beta$-lapachone (i.e., phenazines) and have attracted considerable attention due to their biological activities, including antimalarial ${ }^{5}$, antimycobacterial ${ }^{2}$, antitumor, and antiparasitic ${ }^{21}$ ones. Therefore, the use of this group of compounds as pharmacophores for the development of new drugs has consequently been investigated.

In this study, lapachol, $\beta$-lapachone and three of its derivatives, and 17 phenazines synthesized from $\beta$-lapachone analogues were tested against $T$. canis larvae.

\section{MATERIALS AND METHODS}

Synthesis: Lapachol was extracted from the heartwood of Tabebuia spp (Tecoma) and purified by recrystallization from ethanol, following a previously described procedure ${ }^{11}$. Nor-lapachol was synthesized from lapachol through Hooker oxidation ${ }^{14}$.

$\beta$-lapachone, nor- $\beta$-lapachone, and $\beta$-C-allyl-lawsone were obtained through the cyclisation of the prenyl side chain of lapachol, nor-lapachol and C-allyl-lawsone, respectively. $10 \mathrm{mmol}$ of the naphthoquinone were solubilized in $15 \mathrm{~mL}$ of sulfuric acid and mixed for several minutes. The reaction was poured over cold water. The red solid was filtered, washed with cold water $(3 \times 100 \mathrm{~mL})$ and purified by recrystallization using a mixture of acetone/hexane ${ }^{17}$.

The phenazines were prepared by the reaction of the naphthoquinone $(1.00 \mathrm{mmol}), o$-phenylenediamine $(1.10 \mathrm{mmol})$ and sodium acetate $(1.30 \mathrm{mmol})$ in glacial acetic acid $(50 \mathrm{~mL})$. The reaction was maintained under reflux for two hours and monitored by TLC. After the reaction, the mixture was poured over ice and left to incubate overnight. The yellow precipitate was filtered through a Buchner funnel, washed with cold water $(3 \times 100 \mathrm{~mL})$, and the phenazine was isolated. All phenazines were synthesized with $>95 \%$ yield $^{35}$.

Test compounds: All synthesized compounds were solubilized in DMSO at $2.5 \%\left(\right.$ Sigma $\left.{ }^{\circledR}\right)$ and in sterile distilled water to obtain a concentration of $2 \mathrm{mg} / \mathrm{mL}^{33}$.

Preparation of $\boldsymbol{T}$. canis larvae: $T$. canis eggs were initially collected directly from the uterine tubes of female adult parasites following the treatment of young dogs with pyrantel pamoate $(15 \mathrm{mg} / \mathrm{kg})$. Afterwards, the eggs were incubated in a $2 \%$ formalin solution at $28{ }^{\circ} \mathrm{C}$ for 30 days in a humidity of $>90 \%{ }^{27}$. By using a $5 \%$ sodium hypochlorite solution (Vetec), the eggs' protein cover was dissolved and the hatched T. canis larvae were collected in sterile tubes for cultivation with a (Gibco) RPMI1640 medium supplemented with (Sigma) 25mM HEPES, $1 \%$ glucose, (Gibco) PSF antibiotic-antimycotic solution, and $0.4 \mu \mathrm{g} / \mathrm{mL}$ ofloxacin. Samples were maintained at $37{ }^{\circ} \mathrm{C}$ strain with $5 \% \mathrm{CO}_{2}$.

Larvicidal/larvistatic activity test: A microplate was used to measure the activity of substances at a concentration of $2 \mathrm{mg} / \mathrm{mL}$. The tests were conducted in duplicate. $100 \mathrm{~T}$. canis larvae, $200 \mu \mathrm{L}$ of RPMI1640 medium, and $100 \mu \mathrm{L}$ of the test substances were added in each well. The larvae were then maintained at $37{ }^{\circ} \mathrm{C}$ for 48 hours with $5 \% \mathrm{CO}_{2}$.

The activity was tested in vitro and after exposure to the test compound the larval mobility was tested by the state of the larvae (i.e., motile, immobile but not dead, or dead). Cell viability was tested by using a $0.4 \%$ trypan blue indicator.

The substances that showed larvicidal activity in $100 \%$ of larvae with the in vitro test at concentrations of $2 \mathrm{mg} / \mathrm{mL}$ were re-tested at lower concentrations (MLC) (i.e., $1 \mathrm{mg} / \mathrm{mL}, 0.5 \mathrm{mg} / \mathrm{mL}, 0.25 \mathrm{mg} / \mathrm{mL}, 0.125 \mathrm{mg} / \mathrm{mL}$ and $0.05 \mathrm{mg} / \mathrm{mL}$ ). Afterwards, the substances with larvicidal/larvistatic activity at the lowest concentrations were assessed for their viability of infection in mice. In order to assess their viability, the content of each microplate well was inoculated into 5-week-old BALB/c female mice by intraperitoneal injection. All mice were given food without antibiotics and had free access to water. The mice were kept on a 12 hour light to 12 hour dark cycle at a $22{ }^{\circ} \mathrm{C}\left( \pm 2{ }^{\circ} \mathrm{C}\right)$ room temperature.

Furthermore, a control group of live larvae (100 larvae/well) in mice was used to confirm the viability of larvae that were not exposed to the substances. A single mouse was used for each compound and each control. Mice were euthanized after 30 days of inoculation. The animals were examined for larvae by having their carcass, brain, liver, lungs, kidneys, heart, eyes, and spleen digested in a solution of $1 \%$ hydrochloric acid and $1 \%$ pepsin $^{39}$.

\section{RESULTS}

Lapachol, $\beta$-lapachone and three of its derivatives, and 17 phenazines were tested against $T$. canis larvae.

$\beta$-lapachone and $\beta$-C-allyl-lawsone showed the highest activity $(\mathrm{MLC}=0.25 \mathrm{mg} / \mathrm{mL})$, followed by lapachol $(\mathrm{MLC}=0.5 \mathrm{mg} / \mathrm{mL})$ and nor-lapachol (MLC = $1 \mathrm{mg} / \mathrm{mL})$ (Table 1$)$.

Out of the 17 phenazines tested on T. canis larvae, four compounds (i.e., compounds $1,2,3$, and 4 ) showed $100 \%$ activity at a concentration of $2 \mathrm{mg} / \mathrm{mL}$. Additionally, three compounds (i.e., compounds 5, 16, and 17) showed a larvicidal activity of $78.6-98.4 \%$ at the same concentration. The other phenazines showed $<14 \%$ activity (Table 2 ).

The larvae exposed to the compounds with $100 \%$ activity in vitro were not viable and, therefore, were not able to infect the mice. The control group consisted of live larvae and caused infection when inoculated into the mice, which validates the in vitro evaluation criteria used in this study.

\section{DISCUSSION}

The search for new therapeutic prototypes with effectiveness against T. canis larvae housed in human tissues is relevant for the efficacy of visceral toxocariasis treatment. The new drugs should eradicate all larvae housed in the tissues, not only decrease the intensity of infection as it was noted in the administration of albendazole ${ }^{1,6,32,33}$, ivermectin, mebendazole, and thiabendazole ${ }^{22}$ in mice.

In this study, the possible effect of lapachol and $\beta$-lapachone and its derivatives against T. canis larvae was tested. Among all the synthetic compounds tested, $\beta$-lapachone and $\beta$-C-allyl-lawsone showed the best anthelmintic activity in vitro. Although these results are relevant, the quinones present significant toxicity, possibly due to the redox potential. This toxicity may cause cell damage due to oxidative stress, which could result in undesirable side effects ${ }^{10}$. 
Table 1

Larvicide/larvistatic activity, MLC and in vivo viability of the T. canis larvae treated with lapachol and derivatives $(\mathrm{n}=5)$

Chemical compound
Activity $\begin{gathered}\text { Standart } \\ \text { deviation }\end{gathered} \quad$ LLC<smiles>CC1(C)CC(=O)C(=O)c2ccccc21</smiles>

Nor- $\beta$-lapachone

$$
\mathrm{C}_{14} \mathrm{H}_{12} \mathrm{O}_{3}
$$

$\beta$-C-allyl-lawsone $\mathrm{C}_{13} \mathrm{H}_{10} \mathrm{O}_{3}$<smiles>CC1CC2=C(O1)c1ccccc1C(=O)C2=O</smiles>

Live larvae (no compound)
$4.2 \%$

0.4
Negative

Control

Positive to detection of

Negative to detection of $T$. canis larvae in mice tissues; Positive to detection of $T$. canis larvae in mice tissues.

Nevertheless, due to the presence of larvicidal activity and by the easy access of quinones to natural sources from Brazilian flora ${ }^{7}$, justify the utilization of these compounds as a pharmacophore to develop heterocyclic derivatives more active and less toxic.

This approach was previously used to synthesize trypanocidal naphthoimidazoles from $\beta$-lapachone and to demonstrate that naphthoimidazoles were more active and less toxic than $\beta$-lapachone ${ }^{8}$.

The larvicidal potential of in vitro tests and the capacity to inhibit viability of infection in the mice, demonstrated by quinones, indicated the relevance of studies in this area. Furthermore, motivates realize cytotoxicity studies, for further evidence of the biological activity of these compounds, in preclinical trials in experimental models, aiming the development of prototype compound with anthelmintic activity which could be used in the treatment of visceral toxocariasis.

Four phenazines (i.e., compounds 1, 2, 3, and 4) out of the 17, showed $100 \%$ activity at a concentration of $2 \mathrm{mg} / \mathrm{mL}$. However, these phenazines did not present satisfactory results when exposed to low concentrations; similar results were obtained with the same phenazines against Plasmodium falciparum, P. berghei ${ }^{5}$, and Mycobacterium tuberculosi ${ }^{2}$. In these studies, the compounds showed $50 \%$ antimalarial activity in vitro, and only one-fourth of the phenazines tested against $M$. tuberculosis demonstrated strong antimycobacterial activity (minimum inhibitory concentration $=0.78 \mu \mathrm{g} / \mathrm{mL}$ ). A significant antimalarial activity in vitro was also shown in the other phenazines synthesized from naphthols that were assayed against $P$. falciparum strains resistant to chloroquine. However, they are not able to promote an effective cure when tested against $P$. berghei in vivo ${ }^{20}$. 
MATA-SANTOS, T.; PINTO, N.F.; MATA-SANTOS, H.A.; DE MOURA, K.G.; CARNEIRO, P.F.; CARVALHO, T.S.; DEL RIO, K.P.; PINTO, M.C.F.R.; MARTINS, L.R.; FENALTI, J.M.; DA SILVA, P.E.A. \& SCAINI, C.J. - Anthelmintic activity of lapachol, $\beta$-lapachone and its derivatives against Toxocara canis larvae. Rev. Inst. Med. Trop. Sao Paulo, 57(3): 197-204, 2015.

Table 2

Larvicide/larvistatic activity, MLC and in vivo viability of the T. canis larvae treated with phenazines ( $\mathrm{n}=17)$

No. Chemical structure $\quad$ Chemical compound Activity $\begin{gathered}\text { Standart } \\ \text { deviation }\end{gathered}$ MLC<smiles>CC1(C)CCc2c(c3c(c4nc5ccccc5nc24)CCCC3)O1</smiles>

$\begin{array}{llll}\mathrm{C}_{21} \mathrm{H}_{22} \mathrm{~N}_{2} \mathrm{O} & 100 \% & \text { Zero } & 2,000 \mu \mathrm{g} / \mathrm{mL}\end{array}$<smiles>CC(C)CCC1=C(OC2(CCC(C)C)C(=O)C3=C(CCCC3)c3nc4ccccc4nc32)C(=O)C2=C(CCCC2)C1=O</smiles>

$\mathrm{C}_{36} \mathrm{H}_{42} \mathrm{~N}_{2} \mathrm{O}_{4} \quad 100 \% \quad$ Zero $\quad 2,000 \mu \mathrm{g} / \mathrm{mL} \quad$ Negative<smiles>CCCc1c(O)c2ccccc2c2nc3ccccc3nc12</smiles>

$\mathrm{C}_{19} \mathrm{H}_{16} \mathrm{~N}_{2} \mathrm{O} \quad 100 \% \quad$ Zero $\quad 2,000 \mu \mathrm{g} / \mathrm{mL} \quad$ Negative

4<smiles>CC1Cc2c(c3c(c4nc5ccccc5nc24)CCCC3)O1</smiles>

$\mathrm{C}_{19} \mathrm{H}_{18} \mathrm{~N}_{2} \mathrm{O} \quad 100 \% \quad$ Zero $\quad 2,000 \mu \mathrm{g} / \mathrm{mL} \quad$ Negative

5<smiles>CC(C)Cc1c(O)c2c(c3nc4ccccc4nc13)CCCC2</smiles>

$\mathrm{C}_{20} \mathrm{H}_{22} \mathrm{~N}_{2} \mathrm{O} \quad 78.6 \%$

7.1

$\mathrm{C}_{36} \mathrm{H}_{34} \mathrm{~N}_{2} \mathrm{O}_{4} \quad 1.76 \%$

0.03 


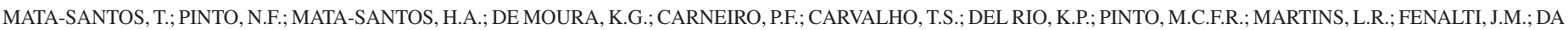
SILVA, P.E.A. \& SCAINI, C.J. - Anthelmintic activity of lapachol, $\beta$-lapachone and its derivatives against Toxocara canis larvae. Rev. Inst. Med. Trop. Sao Paulo, 57(3): 197-204, 2015.

Table 2

Larvicide/larvistatic activity, MLC and in vivo viability of the T. canis larvae treated with phenazines $(\mathrm{n}=17)$ (cont.)

No. Chemical structure Chemical compound Activity $\begin{gathered}\text { Standart } \\ \text { deviation }\end{gathered} \quad \begin{gathered}\text { MLC } \\ \text { mice }\end{gathered}$

7<smiles>CC(C)CC1=C(OCC2(CC(C)C)Nc3ccccc3Nc3ccccc32)C(=O)c2ccccc2C1=O</smiles>
$\mathrm{C}_{34} \mathrm{H}_{30} \mathrm{~N}_{2} \mathrm{O}_{4}$
$1.0 \%$
0.1

8<smiles>CC(C)CC1=C(OC2(CC(C)C)C(=O)C3=C(CCCC3)c3nc4ccccc4nc32)C(=O)C2=C(CCCC2)C1=O</smiles>

$\mathrm{C}_{34} \mathrm{H}_{38} \mathrm{~N}_{2} \mathrm{O}_{4}$

$3.8 \%$

18.0

9<smiles>CC(C)Cc1c(O)c2ccccc2c2nc3ccccc3nc12</smiles>

$\begin{array}{lll}\mathrm{C}_{20} \mathrm{H}_{18} \mathrm{~N}_{2} \mathrm{O} & 4.2 \% & 8.8\end{array}$

10<smiles>CC(C)=Cc1c(O)c2ccccc2c2nc3ccccc3nc12</smiles>

$\mathrm{C}_{20} \mathrm{H}_{16} \mathrm{~N}_{2} \mathrm{O}$

$1.3 \%$

4.5

11<smiles>C=CCC1=C(OC2(CC=C)C(=O)c3ccccc3-c3nc4ccccc4nc32)C(=O)c2ccccc2C1=O</smiles>

$\mathrm{C}_{32} \mathrm{H}_{22} \mathrm{~N}_{2} \mathrm{O}_{4}$

$6.5 \%$

2.2

12<smiles>CCCC1=C(OC2(CCC)C(=O)c3ccccc3-c3nc4ccccc4nc32)C(=O)c2ccccc2C1=O</smiles>

$\mathrm{C}_{32} \mathrm{H}_{26} \mathrm{~N}_{2} \mathrm{O}_{4}$

$1.5 \%$

1.1 


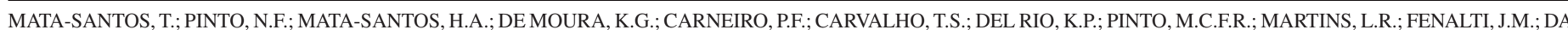
SILVA, P.E.A. \& SCAINI, C.J. - Anthelmintic activity of lapachol, $\beta$-lapachone and its derivatives against Toxocara canis larvae. Rev. Inst. Med. Trop. Sao Paulo, 57(3): 197-204, 2015.

Table 2

Larvicide/larvistatic activity, MLC and in vivo viability of the T. canis larvae treated with phenazines $(\mathrm{n}=17)($ cont.)

No. Chemical structure Chemical compound Activity $\begin{gathered}\text { Standart } \\ \text { deviation }\end{gathered} \quad$ MLC $\quad$ Larvae viability in

13<smiles>CCCc1c(O)c2c(c3nc4ccccc4nc13)CCCC2</smiles>

$\begin{array}{lll}\mathrm{C}_{19} \mathrm{H}_{20} \mathrm{~N}_{2} \mathrm{O} & 14.0 \% & 47.4\end{array}$<smiles>CC1(C)Cc2c(c3c(c4nc5ccccc5nc24)CCCC3)O1</smiles>

$\begin{array}{lll}\mathrm{C}_{20} \mathrm{H}_{20} \mathrm{~N}_{2} \mathrm{O} & 2.5 \% & 1.4\end{array}$

15<smiles>CC1(C)CCc2c(c3ccccc3c3nc4c(nc23)CCCC4)O1</smiles>

$\mathrm{C}_{21} \mathrm{H}_{22} \mathrm{~N}_{2} \mathrm{O} \quad 4.0 \%$

0.7

16<smiles>CC(C)=CCC1=C(OC2(CC=C(C)C)C(=O)c3ccccc3-c3nc4ccccc4nc32)C(=O)c2ccccc2C1=O</smiles>

$\begin{array}{lll}\mathrm{C}_{36} \mathrm{H}_{30} \mathrm{~N}_{2} \mathrm{O}_{4} & 94.5 \% & 3.5\end{array}$<smiles>CC1CCC2CC(C)(C)Oc3c(c4nc5ccccc5nc4c4ccccc34)C2C1</smiles>

$98.4 \%$

0.4

17

$\begin{array}{lll}- & 98.4 \% & 0.4\end{array}$

\section{CT}

No compound

$1.3 \%$

0.4

Positive

CT: Control; Negative to detection of T. canis larvae in mice tissues; Positive to detection of T. canis larvae in mice tissues.

Structural changes that arose in other phenazines (i.e., compound 5-17) tested in this study did not increase the specific activity of the molecules. The lower activity of compounds 5-17, compared to compounds 1-4, indicates that new modifications to these molecules are necessary to promote effective action against $T$. canis larvae. 


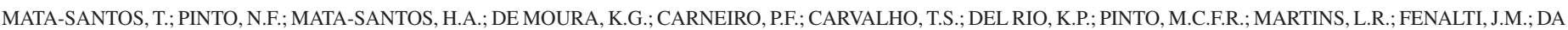
SILVA, P.E.A. \& SCAINI, C.J. - Anthelmintic activity of lapachol, $\beta$-lapachone and its derivatives against Toxocara canis larvae. Rev. Inst. Med. Trop. Sao Paulo, 57(3): 197-204, 2015.

\section{ACKNOWLEDGEMENTS}

The authors are grateful to Antônio Ventura Pinto and Núcleo de Pesquisa de Produtos Naturais (UFRJ) for the compounds.

\section{FINANCIAL SUPPORT}

This work was supported by Coordenação de Aperfeiçoamento de Pessoal de Nível Superior. Authors declare no conflict of interests.

\section{RESUMO}

\section{Atividade anti-helmíntica do lapachol, $\beta$-lapachona e derivados contra larvas de Toxocara canis}

Os anti-helmínticos empregados no tratamento das helmintoses intestinais, de modo geral, são eficazes, porém nas parasitoses teciduais, como é o caso da toxocaríase visceral, a eficácia é moderada. Este estudo teve como objetivo avaliar in vitro a atividade do lapachol, $\beta$-lapachona e fenazinas derivadas da $\beta$-lapachona sobre a viabilidade de larvas de Toxocara canis. Os compostos foram testados na concentração de $2 \mathrm{mg} / \mathrm{mL}$ (em duplicata) em placas de microcultivo, contendo larvas de $T$. canis em meio RPMI-1640, sendo incubados, a $37{ }^{\circ} \mathrm{C}$, em tensão de $\mathrm{CO} 2$ de $5 \%$, por 48 horas. Na concentração de $2 \mathrm{mg} / \mathrm{mL}$, quatro fenazinas, o lapachol e três derivados, apresentaram atividade larvicida/larvostática de $100 \%$. A seguir, foi realizado o teste de concentração larvicida/larvostártica mínima (CLM). Os compostos que apresentaram os melhores resultados foram o nor-lapachol (CLM, $1 \mathrm{mg} / \mathrm{mL}$ ), lapachol (CLM, 0,5 mg/mL), a $\beta$-lapachona e a $\beta$-C-alil-lausona (CLM, $0,25 \mathrm{mg} / \mathrm{mL})$. As larvas expostas aos compostos, na melhor CLM $100 \%$ in vitro foram inoculadas em camundongos BALB/c saudáveis não sendo capazes de causar infecção, confirmando o potencial larvicida in vitro desses compostos.

\section{REFERENCES}

1. Abo-Shehada MN, Herbert IV. The migration of larval Toxocara canis in mice. II. Postintestinal migration in primary infections. Vet Parasitol. 1984;17:75-83.

2. Coelho TS, Silva RS, Pinto AV, Pinto MC, Scaini CJ, Moura KC, et al. Activity of $\beta$-lapachone derivatives against rifampicin-susceptible and-resistant strains of Mycobacterium tuberculosis. Tuberculosis (Edinb). 2010;90:293-7.

3. Da Silva MN, Ferreira VF, De Souza MCBV. Um panorama atual da química e da farmacologia de naftoquinonas, com ênfase na $\beta$-Lapachona e derivados. Química Nova. 2003;26:407-16.

4. De Almeida ER, da Silva Filho AA, dos Santos ER, Lopes CA. Antiinflammatory action of lapachol. J Ethnopharmacol. 1990;29:239-41

5. De Andrade-Neto VF, Goulart MOF, da Silva Filho JF, da Silva MJ, Pinto MC, Pinto $\mathrm{AV}$, et al. Antimalarial activity of phenazines from lapachol, beta-lapachone and its derivatives against Plasmodium falciparum in vitro and Plasmodium berghei in vivo. Bioorg Med Chem Lett. 2004;14:1145-9

6. Delgado O, Botto C, Mattei R, Escalante A. Effect of albendazole in experimental toxocariasis of mice. Ann Trop Med Parasitol. 1989;83:621-4.

7. De Moura KCG, Emery FS, Neves-Pinto C, Pinto MCFR, Dantas AP, Salomão K, $e$ al. Trypanocidal activity of isolated naphthoquinones from Tabebuia and some heterocyclic derivatives: a review from an interdisciplinary study. J Braz Chem Soc. 2001;12:325-38
8. De Moura KCG, Salomão K, Menna-Barreto RF, Emery FS, Pinto MC, Pinto AV, et al Studies on the trypanocidal activity of semi-synthetic pyran $[b-4,3]$ naphtho[ $[1,2-d]$ imidazoles from $\beta$-lapachone. Eur J Med Chem. 2004;39:639-45.

9. Despommier D. Toxocariasis: clinical aspects, epidemiology, medical ecology, and molecular aspects. Clin Microbiol Rev. 2003;16:265-72.

10. Dubin M, Fernandez-Villamil SH, Stoppani AO. Cytotoxicity of $\beta$-lapachone, an o-naphthoquinone with possible therapeutic use. Medicina (B Aires). 2001;61:343-50

11. Ettlinger MG. Hydroxynaphthoquinones. III. The structure of lapachol peroxide. J Am Chem Soc. 1950;72:3472-4.

12. Falkenberg, MB. Quinonas. In: Simões CMO, Schenkel EP, Gosmann G, Mello JCP, Mentz LA, Petrovick PR, editors. Farmacognosia: da planta ao medicamento. Porto Alegre: Ed. UFRGS; 2004. p. 1102

13. Fan CK, Liao CW, Cheng YC. Factors affecting disease manifestation of toxocarosis in humans: genetics and environment. Vet Parasitol. 2013;193:342-52.

14. Fieser LF, Fieser M. Naphthoquinone antimalarials. XII. The hooker oxidation reaction. J Am Chem Soc. 1948;70:3215-22.

15. Glickman LT, Schantz PM, Cypess RH. Canine and human toxocariasis: review of transmission, pathogenesis, and clinical disease. J Am Vet Med Assoc. 1979;175:1265-

16. Hooker SC. Lomatiol. Part II. Its occurrence, constitution, relation to and conversion into lapachol. Also a synthesis of lapachol. J Am Chem Soc. 1936;58:1181-90.

17. Hooker SC. The constitution of lapachol and its derivatives. Part IV. Oxidation with potassium permanganate. J Am Chem Soc. 1936;58:1168-73.

18. Hotez PJ, Wilkins PP. Toxocariasis: America's most common neglected infection of poverty and a helminthiasis of global importance? PLOS Negl Trop Dis. 2009;3:400

19. Hussain H, Krohn K, Ahmad VU, Miana GA, Green IR. Lapachol: an overview. Arkivoc. 2007; $2: 145-71$

20. Hussain H, Specht S, Sarite SR, Saeftel M, Hoerauf A, Schulz B, et al. A new class of phenazines with activity against a chloroquine resistant Plasmodium falciparum strain and antimicrobial activity. J Med Chem. 2011;54:4913-7.

21. Laursen JB, Nielsen J. Phenazine natural products: biosynthesis, synthetic analogues and biological activity. Chem Rev. 2004;104:1663-85.

22. Lescano SZ, Chieffi PP, Amato Neto V, Ikai DK, Ribeiro MCSA. Anthelmintics in experimental toxocariasis: effects on larval recovery of Toxocara canis and on immune response. J Bras Patol Med Lab. 2005;41:21-4.

23. Lima NMF, Correia CS, Leon LL, Machado GMC, Madeira MF, Santana AEG, et al. Antileishmanial activity of lapachol analogues. Mem Inst Oswaldo Cruz. 2004;99:757-61

24. Lopes JN, Cruz FS, Docampo R, Vasconcellos ME, Sampaio MC, Pinto AV, Gilbert B. In vitro and in vivo evaluation of the toxicity of 1,4-naphthoquinone and 1,2-naphthoquinone derivatives against Trypanosoma cruzi. Ann Trop Med Parasitol $1978 ; 72: 523-31$

25. Magnaval JF. Comparative efficacy of diethylcarbamazine and mebendazole for the treatment of human toxocariasis. Parasitology. 1995;110:529-33.

26. Maizels RM. Toxocara canis: molecular basis of immune recognition and evasion. Vet Parasitol. 2013;193:365-74

27. Nunes CM. Imunodiagnóstico da larva migrans visceral através de um método de ELISA indireto competitivo. [Tese]. São Paulo: Universidade de São Paulo, Faculdade de Medicina Veterinária e Zootecnia; 1996. 
MATA-SANTOS, T.; PINTO, N.F.; MATA-SANTOS, H.A.; DE MOURA, K.G.; CARNEIRO, P.F.; CARVALHO, T.S.; DEL RIO, K.P.; PINTO, M.C.F.R.; MARTINS, L.R.; FENALTI, J.M.; DA SILVA, P.E.A. \& SCAINI, C.J. - Anthelmintic activity of lapachol, ß-lapachone and its derivatives against Toxocara canis larvae. Rev. Inst. Med. Trop. Sao Paulo, 57(3): 197-204, 2015.

28. Othman AA. Therapeutic battle against larval toxocariasis: are we still far behind? Acta Trop. 2012;124:171-8.

29. Pardee AB, Li YZ, Li CJ. Cancer therapy with beta-lapachone. Current Cancer Drug Targets. 2002;2:227-42.

30. Pawlowski Z. Toxocariasis in humans: clinical expression and treatment dilemma. J Helminthol. 2001;75:299-305.

31. Quattrocchi G, Nicoletti A, Marin B, Bruno E, Druet-Cabanac M, Preux PM. Toxocariasis and epilepsy: systematic review and meta-analysis. PLOS Negl Trop Dis. 2012;6:1775

32. Reis M, Trinca A, Ferreira MJ, Monsalve-Puello AR, Grácio MAA. Toxocara canis: potential activity of natural products against second-stage larvae in vitro and in vivo. Exp Parasitol. 2010;126:191-7.

33. Satou T, Horiuchi A, Akao N, Koike K, Futja K, Nikaido T. Toxocara canis: search for a potential drug amongst $\beta$-carboline alkaloids - in vivo and mouse studies. Exp Parasitol. 2005;110:134-9.

34. Schneier AJ, Durand ML. Ocular toxocariasis: advances in diagnosis and treatment. Int Ophthalmol Clin. 2011;51:135-44.
35. Silva RSF. Síntese de fenazinas e derivados lactônicos e halogenados a partir de naftoquinonas naturais com atividade contra Mycobacterium tuberculosis. [Tese]. Rio de Janeiro: Universidade Federal do Rio de Janeiro, Núcleo de Pesquisa de Produtos Naturais; 2009.

36. Smith H, Holland C, Taylor M, Magnaval JF, Schantz P, Maizels R. How common is human toxocariasis? Towards standardizing our knowledge. Trends Parasitol. 2009;25:182-8

37. Stürchler D, Schubarth P, Gualzata M, Gottstein B, Oettli A. Thiabendazole vs. albendazole in treatment of toxocariasis: a clinical trial. Ann Trop Med Parasitol. 1989;83:473-8.

38. Torrado S, Torrado S, Cadorniga R, Torrado JJ. Formulation parameters of albendazole solution. Int J Pharm. 1996;140:45-50.

39. Wang GX, Luo ZJ. A novel method for the recovery of Toxocara canis in mice. J Helminthol. 1998;72:183-4.

40. Wisniewska-Ligier M, Wozniakowska-Gesicka T, Sobolewska-Drylariska J, MarkiewiczJógwiak A, Wieczorek M. Analysis of the course and treatment of toxocariasis in children: a long term observation. Parasitol Res. 2012;110:2363-71.

Received: 21 July 2014

Accepted: 22 September 2014 